\title{
PAINTBRUSHES AND CROWBARS: RICHARD RORTY AND THE NEW PUBLIC-PRIVATE DIVIDE
}

\author{
John P. Anderson ${ }^{*}$
}

\begin{abstract}
In an often-quoted passage, Richard Rorty wrote that 'J.S. Mill's suggestion that governments devote themselves to optimizing the balance between leaving people's lives alone and preventing suffering seems to me pretty much the last word." In this Article, I show why, for Rorty, maintaining a strong public-private divide that cordons off final vocabularies - the religious, racial, ethnic, sexual, gender, philosophical, and other terms so important for citizens' private pursuits of self-creation and self-perfection - from public political discourse is a crucial means to accomplishing both of these goals in post-secular liberal democracies. Public political justifications should instead be articulated in the foundationneutral terms of a shared national vocabulary. Like paintbrushes and crowbars, final and shared vocabularies are different tools for different purposes, and a strong public-private divide helps ensure that no harm comes from their misuse.
\end{abstract}

KEY WORDS: Liberal Neutrality, Pluralism, Identity Politics, Politics of Recognition, Humiliation, Solidarity, Post-Secularism

\footnotetext{
* Profess or of Law, Mis sissippi College School of Law.
} 


\section{INTRODUCTION}

The Enlightenment liberal erected a public-private divide to preserve the rule of law by quarantining the subjective influences of religious faith and individual caprice from public political discourse. The idea was to avoid conflict and ensure legitimacy by limiting public political justification to only neutral, "secular" reasons. ${ }^{1}$ For the Enlightenment liberal, this meant limiting political justification to reasons anchored in the terra firma of an objective, universal moral order that is rationally demonstrable from the essential nature of human beings.

Over the last hundred and fifty years or so, however, the West has increasingly been forced to face the contingency of its theoretical foundations in secular reason. Even liberalism's defining commitment to the values of freedom and equality is now commonly traced to historical,

\footnotetext{
${ }^{1}$ See, e.g., Nicholas Wolterstorff, "Why We Should Reject What Liberalis m Tells Us about Speaking and Acting for Religious Reasons", in Religion and Contemporary Liberalism, edited by Paul J. Weithman (University of Notre Dame Press, 1997), 167 (The En lightenment liberal was convinced that the "only way to forestall relig ious wars is to get people to stop invoking God and to stop invoking canonical scriptures when arguing and determining politics.”).
} 
rather than rational, antecedents. I refer to a liberalism that faces this contingency as "post-secular."

Liberalism's historical public-private divide must be rethought and perhaps reconsidered in a post-secular world. Once comprehensive secular theories of identity, right, and good are denied their claim to objectivity, there is no longer any principled justification for elevating them to a privileged status in public political discourse. This has led many to argue that the liberal public-private divide must be cast aside, allowing for open competition among all foundationaljustifications for the use of political power in the public political forum, whether they be religious, ethnic, racial, sexual, gender, philosophical, or other. ${ }^{2}$ Variations of this approach to

\footnotetext{
${ }^{2}$ For some defenses of this open competition model, see, e.g., Stephen L Carter, The Culture of Disbelief (Anchor Books, 1994); Kent Greenawalt, Religious Convictions and Political Choice (New York: Oxford, 1988); Scott C. Idleman, "The Concealment of Relig ious Values in Judicial Decision Making," Virginia Law Review 91 (2005): 515; Mark Modak-Truran, "Reenchanting the Law: The Religious Dimension of Judicial Decision Making”, Catholic University Law Review, 53 (2004): 709; Michael Perry, "Religious Morality and Political Choice: Further Thoughts - and Second Thoughts - on Love and Power," San Diego law Review 30 (1993): 703. See also, Timothy Jackson's “The Return of the Prodigal? Liberal Theory and Religious Pluralism," Sanford Levinson's “Abstinence and Exclusion: What Does Liberalis m Demand of the Religiously Oriented (Would Be) Judge?," Philip Quinn's, "Political Liberalis ms and Their Exclusions of the Religious," and Nicholas Wolterstorff's, "Why We Should Reject What Liberalism Tells Us About
} 
politics have been identified under a number of labels_- "multiculturalism," "the politics of difference," "the politics of recognition," "cultural politics," or "identity politics"-but I refer it more generally as the open competition model.

Richard Rorty saw things differently. For Rorty, the post-secular world signals liberalism's coming of age. It puts liberal democracies in a position to "throw away some of the ladders used in their own construction" and to free themselves from Enlightenment foundationalism altogether. ${ }^{3}$ In this spirit, Rorty argues that the best way to address the contingency of comprehensive secular justifications in a post-secular world is to force them onto the private side of the private-public divide, not to eliminate the divide itself. ${ }^{4}$ This strategy has the effect of limiting public political discourse to Speaking and Acting in Public for Religious Reasons," collected in Religion and Contemporary Liberalism, Paul J. Weithman, ed. (South Bend: University of Notre Dame Press, 2009).

3 Richard Rorty, Contingency, Irony, and Solidarity (Cambridge University Press, 1989), 194.

${ }^{4}$ There is little consensus on where Rorty would draw the line between the public and the private, and Rorty was never explicit on this point. Some suggest that Rorty regarded any arguments concerning politics that are offered to the general public should be regulated by the public-private divide. See, e.g., Nicholas Wolterstorff, "An Engagement with Rorty," in Understanding Liberal Democracy (Oxford, 2012), p. 47. And there are passages in Rorty that lend credence to this expansive interpretation. I have always 
only "freestanding,"5 foundation-neutral reasons-what Rorty referred to as a political society's "shared vocabulary" 6 and what John Rawls referred to as its "public reason." "I refer to this approach to politics as the foundationneutral model for politics.

understood Rorty to advocate a much more limited scope for the public side of the divide, something along the lines of what John Rawls understood to be the limits of public reason. On this view, the public-private divide regulates only public political discourse concerning the constitutional essentials of a society by citizens who are acting in some official capacity (e.g., as a government official, representative, or judge) or when voting. See, e.g., John Rawls, Political Liberalism, Expanded Edition, 211-54 (Columbia, 2005). On this view, not all political subjects are regulated by the public private divide (only those that pertain to constitutional essentials), and discussion of even constitutional essentials is not regulated by the divide when they take place in civil society. That said, since the willingness to offer public (i.e., foundation-neutral) reasons for controversial positions in even civil society is a virtue in a liberal society because it reflects a spirit of cooperation and mutual respect. I think it is fair to identify Rorty's conception of the scope of the public sphere with Rawls's because Rorty constantly relies on Rawls in articulating his own defense of the publicprivate divide. See generally, Richard Rorty, "The Priority of Democracy to Philosophy," in Objectivity, Relativism, and Truth (Cambridge University Press, 1991), at pp. 175-196. In any event, it is certainly safe to say that Rorty would include Rawls's conception of the public within his own, even if he would have preferred that it be expanded still further.

${ }^{5}$ See, e.g., Rawls, Political Libera lis m, 13.

${ }^{6}$ Rorty, Contingency, xvi.

7 See, e.g., John Rawls, "The Idea of Public Reason Revisited," in Political 
Rorty was adamant that, even in a post-secular world, maintaining a strong private-public divide under the foundation-neutral model is crucial to promoting and protecting the values we cherish most in the West: (1) the freedom of the individual to engage in private projects of self-creation and self-perfection under (2) social institutions that reflect a spirit of equality, cooperation, and mutual respect. While private foundational reasons that rely crucially on religious, racial, ethnic, sexual, gender, or philosophical identity may be crucial to our projects of self-creation and self-perfection, they would be counterproductive if applied to the public tasks of promoting equality, cooperation, and mutual respect. Similarly, while a society’s shared vocabulary is well- suited to the tasks of constructing and promoting a just constitutional order, as freestanding, it is useless to private projects. In short, Rorty suggest that, like "paintbrushes and crowbars," final and shared vocabularies are different tools that are best applied to different tasks. $^{8}$ Our rules for public political discourse should continue to reflect this important insight.

Some claim that a foundation-neutral liberal constitutional order is just not possible. ${ }^{9}$ I have argued elsewhere that it is not only possible, but

Liberalism: Expanded Edition (Colu mbia, 2005), 440-490.

${ }^{8}$ Rorty, Contingency, xvi.

${ }^{9}$ See, e.g., Wolterstorff, "Why We Should Reject What Liberalis m Tells Us," 167. 
quite realistic. ${ }^{10}$ My aim here, however, is different. My goal is not to show how justificatory neutrality protected by a strong public-private divide is possible in the post-secular West, but rather to draw on Rorty's work to explain why it remains desirable. I shall begin by saying something about how Rorty understood the new meaning of liberalism's public-private divide in a post-secular West that faces its contingency. In what remains, I lean on Rorty's work to offer some reasons why preserving this divide should continue to be priority for post-secular pluralistic democracies as a means of avoiding cruelty and promoting solidarity.

\section{FACINGCONTINGENCY AND THE NEW PubliC-PRIVATE Divide}

Enlightenment liberals took it as at best self-evident ${ }^{11}$ and at worst rationally demonstrable ${ }^{12}$ that human beings are free and equal. But the

${ }^{10}$ See John P. Anderson, “Law Beyond God and Kant: A Pragmatist Path,” Journal of Law \& Religion (forthcoming, 2017); see also, John P. Anderson, "Trading Truth for Legitimacy in the Liberal State: Defending John Rawls's Pragmatism," Studies in Law, Politics and Society 65, 1-29 (2014); John P. Anderson, "Patriotic Liberalis m," Journal of Law \& Philosophy 22 (2003), 577.

${ }^{11}$ See, e.g., Thomas Jefferson, The Declaration of Independence (US 1776) ("We hold these truths to be self-evident, that all men are created equal, that they are endowed by their Creator with certain unalienable Rights, that among these are Life, Liberty, and the pursuit of Happiness.”).

12 See, e.g., John Locke, Second Treatise of Government (1690, Hackett 1980), 8 (“To 
Enlightenment liberal's confidence in accessing an objective moral order that guarantees these core liberal values has been severely shaken, if not wholly abandoned. ${ }^{13}$ As Rorty put it, Contemporary intellectuals have given up the Enlightenment assumption that religion, myth, and tradition can be opposed to something ahistorical, something common to all human beings qua human. Anthropologists and historians of science have blurred the distinction between innate rationality and the products of acculturation. Philosophers such as Heidegger and Gadamer have given us ways of seeing human beings as historical all the way through. Other philosophers, such as Quine and Davidson, have blurred the distinction between permanent truths of reason and temporary truths of fact.... The result is to erase the picture of the

understand political power right, and derive it from its original, we must consider, what state all men are naturally in, and that is, as state of perfect freedom...[and] A state also of equality...."); Immanuel Kant, Grounding for the Metaphysics of Morals (1785, Hackett 1993), 36 ("If then there is to be a supreme practical principle.... The ground of such a principle is this: rational nature exists as an end in itself.... The practical imperative will therefore be the following: Act in such a way that you treat humanity, whether in your own person or in the person of another, always at the same time as an end and never simply as a means.").

${ }^{13}$ See Anderson, Law Beyond God and Kant. 
self common to Greek metaphysics, Christian theology, and Enlightenment rationalism: the picture of an ahistorical natural center, the locus of human dignity, surrounded by an adventitious and inessential periphery. ${ }^{14}$

While some have argued that facing this contingency means the end of liberalism, Rorty saw it as sign of its maturity. Rorty noted that Max Horkheimer and Theodor Adorno correctly pointed out in their Dialectic of Enlightenment" ${ }^{15}$ that "the forces unleashed by the Enlightenment have undermined the Enlightenment's own convictions."16 From this premise, Horkheimer and Adorno "drew the conclusion that liberalism was now intellectually bankrupt, bereft of philosophical foundations, and that liberal society was morally bankrupt, bereft of social glue."17 In reaching this conclusion, Horkheimer and Adorno assumed that the words the founders of a historical development use to first articulate their vision must be the words that describe it correctly, and consequently that the subsequent dissolution of that terminology must deprive the historical products of the

14 Richard Rorty, "The Priority of Democracy to Philosophy," in Objectivity, Relativism, and Truth (Cambridge University Press, 1991), 176.

${ }^{15}$ Horkheimer and Adorno, Dialectic of Enlightenment, trans. John Cumming (New York: Herder and Herder, 1972).

${ }^{16}$ Rorty, Contingency, 56.

${ }^{17} I d$. 
original vision of the right—or even possibility—of continued existence. ${ }^{18}$ But, according to Rorty, this is almost never the case. ${ }^{19}$ Indeed the opposite is usually true:

the terms used by the founders of a new form of cultural life will consist largely in borrowings from the vocabulary of the culture they are hoping to replace. Only when the new form has grown old, has itself become the target of attacks from the avant-garde, will the terminology of that culture begin to take form. ${ }^{20}$

In other words, Rorty suggested that the final collapse of the Enlightenment need not spell the end of liberalism. On the contrary, it can signal its weaning from the culture it was striving to replace. It offers liberalism its opportunity to reach maturity by finally rejecting the feudalistic tendency to worship a higher authority (whether it be God, the King, or Universal Reason) in favor of freedom. In short, for Rorty, facing its contingency should help liberalism substitute freedom for Truth "as the goal of thinking and of social progress." ${ }^{21}$ Such re-imagination will allow the West to retain Enlightenment liberalism without Enlightenment
${ }^{18} I d$.
${ }^{19} I d$.
${ }^{20} I d$., italics added.
${ }^{21} I d$., xiii. 
rationalism. $^{22}$

But liberalism's commitments to freedom, equality, and the publicprivate divide must take on new meaning in this post-secular world. To begin, where one can no longer rely on a universal moral order imposed from without, the Enlightenment commitment to freedom as the capacity to act out of respect for universal moral law (ala $\mathrm{Kant}^{23}$ ) is replaced by the commitment to freedom as the ability to engage in the ongoing projects of self-creation and self-perfection.

\section{Freedom as Self-Invention}

For Rorty, freedom in the face of contingency is a matter of selfinvention. It is reflected in the ongoing and constantly evolving activity of creating and recreating an original ideal self-description and making it manifest through action. It is practical poetry. For Rorty, the "hope of such a poet is that what the past tried to do to her she will succeed in doing to the past: to make the past itself, including those very causal processes which blindly impressed all her own behavings, bear her impress." 24 Rorty explains that success "in that enterprise-the enterprise of saying "Thus I

\footnotetext{
${ }^{22}$ See, id., 57.

${ }^{23}$ See, e.g., Kant, Grounding.

${ }^{24}$ Rorty, Contingency, 29.
} 
willed it' to the past—is success in what [Harold] Bloom calls 'giving birth to oneself.',"25

According to Rorty, freedom as self-invention is an end in itself for members of Western liberal societies. But, facing contingency, he explains that by "end in itself" he means a "project [he] cannot imagine defending on the basis of noncircular argument." 26 Rorty suggests that writers like Kierkegaard, Nietzsche, Baudelaire, Proust, Heidegger, and Nabokov are exemplars "of what private perfection-self-created, autonomous, human life-can be like."27 But one needn't be a genius or even artistically inclined to engage in this project. For Rorty, the intellectual, "the person who uses words or visual or musical forms" in her private pursuit of selfperfection, "is just a special case." 28 The intellectual is

just somebody who does with marks and noises what other people do with their spouses and children, their fellow workers, the tools of their trade, the cash accounts of their businesses, the possessions they accumulate in their homes, the music they listen to, the sports they play or watch, or the trees they pass on their way to work. Anything from the sound of a word through the color of a leaf to

${ }^{25} I d ., 29$.

${ }^{26} I d ., 64$ at n. 24.

${ }^{27}$ Id., xiv .

${ }^{28} I d ., 37$. 
the feel of piece of skin can, as Freud showed us, serve to dramatize and crystallize a human being's sense of self-identity. For any such thing can play the role in an individual life which philosophers have thought could, or at least should, be played only by things which were universal, common to us all...Any seemingly random constellation of such things can set the tone of a life. Any such constellation can set up an unconditional commandment to whose service a life may be devoted-a commandment no less unconditional because it may be intelligible to, at most, only one person. ${ }^{29}$

${ }^{29}$ Id. For another account of freedom that faces contingency, see George Kateb's list of "sentiments of democratic self-as sertion":

(1) the wish to be different; the wish to be unique; the wish to go off in one's own direction; the wish to experiment, to wander, to float;

(2) the wish to be let alone; the wish to be uninvolved in somebody else's game; the wish to be unobserved; the wish to be mysterious, to have secrets, to be thought undefined;

(3) the wish to be unbeholden; the wish to own oneself;

(4) the wish to think, judge, and interpret for oneself;

(5) the wish to feel real, not dazed; the wish to live, not play just one lifelong role or perform just one life long function;

(6) the wish to go to one's limit; the wish to score, to accumulate heterogeneous experiences; 


\section{From Freedom to Equality and the New Public-Private Divide}

The exercise of this freedom demands a zone of privacy in which individuals have the opportunity to pursue these all-important projects without undue interference, and in an environment conducive to self-respect. This zone of privacy must therefore be policed and protected by a public constitutional order ${ }^{30}$ that, to respect the liberal commitment to equality, is

(7) the wish to shape one's life, but not into a well-shaped story, or a well-made work of art; the wish to be fluid, not substantial;

(8) the wish to find oneself, to find the 'real me'; to be oneself rather than somebody else's idea of that self; the wish to be reborn as oneself.

"Democratic Individuality and the Meaning of Rights," in Liberalism and the Moral Life, ed. Nancy L. Rosenblum (Harvard University Press, 1989) 183, 191.

${ }^{30}$ This commitment to a zone of privacy is articulated and recognized in a number of U.S. Supreme Court decisions. In Bowers v. Hardwick, Justice Blackmun exp lains that the right to privacy both decisional and special aspects: "In construing the right to privacy, the Court has proceeded along two somewhat distinct, albeit complementary lines. First, it has recognized a privacy interest with reference to certain decisions that are properly for the individual to make. Second, it has recognized a privacy interest with reference to certain places without regard for the particular activities in which the individuals who occupy them are engaged." 478 U.S. 186, 203-204 (1986) (dissenting) (internal citations omitted). The Court has recognized that the right to privacy is just part of the broader "right to be let alone.” Olmstead v. United States, 277 U.S. 438, 478 (1928) (Brandeis, J., dissenting). 
justified in terms all citizens can be expected to accept. ${ }^{31}$ Rawls refers to this requirement of justificatory neutrality as the liberal principle of reciprocity. ${ }^{32}$ But in the post-secular West, articulating the scope and justifying the enforcement of this zone of privacy is a very different project from that of self-creation, and one that demands talents and methods of a different sort.

Rorty distinguishes writers who focus on the private pursuits of selfcreation and self-perfection from writers like Mill, Dewey, Habermas, and Rawls who focus on equality, justice, and legitimacy. The latter are "fellow citizens rather than exemplars." 33 These authors "are engaged in a shared social effort - the effort to make our institutions and practices more just and

31 See, e.g., Bowers, 478 U.S. at 211 ("The legitimacy of...legislation depends...on whether the State can advance some justification for its law beyond its conformity to religious doctrine.”) (Blackmun, J., dissenting).

${ }^{32}$ See, e.g., Rawls, The Idea of Public Reason Revisited, xliv ("our exercise of political power is proper only when we sincerely believe that the reasons we offer for our political action may reasonably be accepted by other citizens as a justification for those actions"). See also, Gerald Gaus, The Order of Public Reason (Cambridge, 2012), 19 ("to respect others as free and equal moral persons is to refrain from claiming moral authority over them to demand that they do what they do not themselves have reason to endorse"); Abdullahi Ahmen An-Na'Im, Islam and the Secular State (Harvard, 2008), 127.

${ }^{33}$ Rorty, Contingency, xiv. 
less cruel."34 Rorty goes on that we "shall only think of these two kinds of writers as opposed if we think that a more comprehensive philosophical outlook would let us hold self-creation and justice, private perfection and human solidarity, in a single vision."35 Again, if it has done anything, facing contingency in the post-secular West should force liberals to recognize this is not possible. According to Rorty, the closest we will ever come "to joining these two quests is to see the aim of a just and free society as letting its citizens be as privatistic, irrationalist, and aestheticist as they please so long as they do it on their own time-causing no harm to others and using no resources needed by those less advantaged."36

So, for Rorty, it is best to think of the relation between writers who offer reasons in support of projects of self-creation and writers who offer reasons in support of social justice and equality "as being like the relation between two kinds of tools-as little in need of synthesis as are paintbrushes and crowbars." ${ }^{, 37}$ Rorty explains,

One sort of writer lets us realize that the social virtues are not the only virtues, that some people have actually succeeded in recreating themselves. We thereby become aware of our own half-
${ }^{34} I d$.
${ }^{35} I d$.
${ }^{36} I d$.
${ }^{37} I d$. 
articulate need to become a new person, one whom we as yet lack words to describe. The other sort reminds us of the failure of our institutions and practices to live up to the convictions to which we are already committed by the public, shared vocabulary we use in daily life.... Both are right, but there is no way to make both speak a single language. ${ }^{38}$

The task of the public-private divide in a post-secular society is to ensure these tools are applied to their proper purpose.

To summarize, Rorty insisted that maintaining a strong publicprivate divide that excludes vocabularies of self-creation (i.e., the religious, racial, ethnic, sexual, gender, philosophical, and other commitments with which citizens build their most intimate self-conceptions) from public political justification under the foundation-neutral model is crucial to meeting liberalism's dual goals of respecting freedom and equality in a post-secular world. To fully appreciate why maintaining the divide is so important; we need to understand the different and incommensurable roles the values of freedom and equality play in a liberal society that faces its contingency. When we give up on the Enlightenment idea of capturing a theory of freedom and equality in a single comprehensive doctrine that is authoritative for all humans as such, then freedom as the pursuit of self-

\footnotetext{
${ }^{38} I d$., xiv-Xv .
} 
perfection, and equality as the recognition that this freedom must be ordered so as to show equal respect, each require separate justifications. Justifications for private projects of self-creation can be as foundational, comprehensive and as aestheticist as one pleases, but the public effort to order these private projects pursuant to the liberal commitment to equality must be uncontroversial, which, in a society that faces contingency, means it must be foundation-neutral. In short, freedom plays a private role; equality plays a public role; and contingency forces us to recognize that these roles must be separate and distinct to be successful. But isn't this just a bunch of esoteric philosophical quibbling? One might wonder what, precisely, is the harm that would result from leveling this divide? Rorty was convinced that allowing final vocabularies to openly vie for, and justify the use of, political power would inevitably humiliate citizens and undermine solidarity. This is the focus of the next two sections.

\section{FREEDOM AND HUMILIATION}

Rorty pointed out that while humans and other animals all share the capacity to feel pain, humans can "be given a special kind of pain: They can all be humiliated by the forcible tearing down of the particular structures of language and belief in which they were socialized (or which they pride 
themselves on having formed themselves)." ${ }^{39}$ Officially justifying the use of political power by appeal to foundational reasons (religious, racial, ethnic, sexual, gender, philosophical, or other) that are shared by some but not all, is one of the most effective means of forcibly tearing down these structures in a pluralistic society. Such justification humiliates by drawing political power indiscriminately from all citizens, but exercising it in the name of only a few, thereby forcing some citizens to be complicit in the promotion of comprehensive worldviews to which they do not subscribe and may be adamantly opposed. Such humiliation is unavoidable when the public-private divide is leveled in favor of the open competition model.

Proponents of open competition may respond that it should make no difference that a law is officially justified by appeal to, say, Christian principles, so long as it is neutral in effect. For example, one might argue that the scope of a constitutional right to equal protection is not changed by the fact that the framers or judges expressly justify it as deriving from the New Testament. But, even if this were true, is there any doubt that a Muslim, Jew, or atheist would suffer humiliation when forced to avail herself of a protection so justified ${ }^{40}$ The effect is the same as that of telling

\footnotetext{
${ }^{39}$ Id., 177.

${ }^{40}$ The harm is compounded further when such reasons are offered to justify the use of coercive power against one who does not share them. See, e.g., Chicoine v. Chicoine, 479
} 
an African American child that she is not harmed by being forced to attend a different school from whites because the schools are equal in all other respects. The harm is in the humiliation that results from the segregation itself, from the state recognition that there are two classes of children. ${ }^{41}$ The democratic process may itself be free and fair under the open competition model, but the conclusion of the process tends to yield two classes of final vocabularies: those that rule (i.e., stand as the official justification for the exercise of state power) and those that must submit. The former are empowered, and the latter are rendered powerless and humiliated. The final vocabularies (religious, racial, ethnic, sexual, gender, philosophical, or other) that win out in open competition become, for example, "American," and those that lose, "Un-American." Rorty taught us that people who value freedom do not want to be forcibly redescribed by

N.W. 2d 891, 896 (S.D. 1992) (in denying a lesbian mother custody of her child, a South Dakota Supreme Court Justice wrote: "Until such time that she can establish, after years of therapy and demonstrated conduct, that she is no longer a lesbian living a life of abomination (see Leviticus 18:22), she should be totally estopped from contaminating these children.").

${ }^{41}$ See Brown v. Board of Education of Topeka, 347 U.S. 483, 494 (1954) ("To separate them from others of similar age and qualifications solely because of their race generates a feeling of inferiority as to their status in the community that may affect their hearts and minds in a way unlikely ever to be undone.”) 
their political institutions in this way. Such redescription is humiliating and therefore cruel.

In sum, final vocabularies are tools we use as we exercise our freedom in our private projects of self-creation and self-perfection. When they are enlisted in the public sphere as justifications for the use of political power, they risk harm to others by forcibly redescribing them. Even if this is not the intention, this is the inevitable result. For liberals like Rorty who see humiliation as one of the worst forms of suffering, avoiding cruelty means recognizing that final vocabularies are simply the wrong tools for the job of social justice. Their role in public political discourse should therefore be regulated by the new public-private divide.

\section{SOCIAL SOLIDARITY AND AUTHORITY}

Rorty helped us to appreciate another reason why it is important for Western liberal democracies to maintain a public-private divide as they face their own contingency. A liberal society is post-secular in part because it no longer considers itself bound together by the dictates of reason or religious faith—by the recognition of "unalienable" natural rights or as being "one nation, under God." Post-secular societies are instead united by 
"common vocabularies and common hopes." 42 Such solidarity "is not discovered by reflection but created;" 43 it is "made rather than found."44 Rorty understood that a strong public-private divide under the foundationneutral model is crucial to forging and reinforcing such solidarity. The open-competition model, by contrast, is often destructive to solidarity. Recall that the open competition model faces post-secular contingency by obliterating the public-private divide and opening public political discourse to all foundational reasons - whether they be, religious, racial, ethnic, sexual, gender, philosophical, or other. Though advocates of the open competition model tend to be guided by the ideals of equal respect, toleration, and diversity, the model itself cannot be presented or justified in terms of these ideals. For if the open competition model itself were justified by appeal to these moral ideals, then some foundational religious or secular story would be needed about why these ideals and not others should be privileged, and why open competition is the best means of achieving them. But if the open competition model itself were ultimately justified by appeal to some such controversial foundational commitments, then there would be no true open competition. The model can only

\footnotetext{
${ }^{42}$ Rorty, Contingency, 86.

${ }^{43}$ Id., xvi.

${ }^{44}$ Id., 195.
} 
overcome this paradox by conceiving itself as offering nothing more than a modus vivendi. ${ }^{45}$

A modus vivendi is a point of equilibrium at which parties who are at odds agree to terms for no other reason than that observing those terms is in their present strategic interest. ${ }^{46}$ But since a balance of interest is all that supports a constitutional order under the open competition model, the rules and principles it issues carry no independent moral authority. They are regarded by citizens from what H.L.A. Hart referred to as the "external point of view."47 Violating such rules and principles offer "a basis for the prediction that a hostile reaction will follow ... [but they do not offer] a reason for hostility."48 From this external viewpoint, citizens will also recognize that, should the present balance of power among competing world views change, the terms of the modus vivendi will change as well. Such recognition plants suspicion among the parties to the modus vivendi (different religious, racial, ethic, sexual, gender, philosophical, and other groups), and creates incentives to find strategic opportunities to increase their relative power in order to better position themselves for the next round

${ }^{45}$ For a more complete discussion of this paradox for the open competition model, see Anderson, "Law Beyond God and Kant."

${ }^{46}$ See, e.g., Rawls, Political Liberalism, 147.

${ }^{47}$ H.L.A. Hart, The Concept of Law (New York: Oxford, 1994), 89.

${ }^{48}$ Id. at 90 . 
of bargaining. Parties may even look to incite conflict with or among other groups to weaken adversaries and garner allies in need of protection. A predictable result of all this is that the public "us" and "them" orientation that the open competition model purports to protect will devolve into an "us"versus "them" mentality. ${ }^{49}$ The symbols of the state (e.g., the flag, the anthem, the pledge of allegiance) eventually come to be seen as symbols of the dominant group. As such, they are loathed by the marginalized as symbols of oppression. The hope for solidarity is replaced by rage and desire for revenge as the nation tears itself apart. Those who endured the U.S. presidential campaign of 2016 know that this narrative of national devolution is neither melodramatic nor fanciful.

Rorty recognized the open competition model's threat to solidarity in his warnings against "multiculturalism," "politics of difference," "cultural politics," "politics of recognition," or "identity politics.",50 For Rorty, in the name of promoting diversity and protecting difference, advocates of open competition often end up repudiating the very "idea of a

${ }^{49}$ See Thomas Pogge, Realizing Rawls (Cornell, 1989), 101-102. Pogge refers to this as the "assurance problem" for modus vivendi.

50 See Richard Rorty, "The Unpatriotic Academy," in Philosophy and Social Hope (Penguin, 1999), 252; Richard Rorty, Achieving Our Country (Harvard, 1997). 
national identity, and the emotion of national pride." 51 For Rorty, in the context of American politics, this

repudiation is the difference between traditional American

Pluralism and the new movement called multiculturalism.

Pluralism is the attempt to make America what the philosopher

John Rawls calls "a social union of social unions," a community of communities, a nation with far more room for difference than

most. Multiculturalism is turning into the attempt to keep these communities at odds with one another. ${ }^{52}$

Rorty was adamant that social progress and social hope presuppose pride in a national moral identity. A "nation cannot reform itself unless it takes pride in itself - unless it has an identity, rejoices in it, reflects upon it, and tries to live up to it." ${ }^{53}$ The open competition model is powerless to articulate such a shared identity. As argued above, it can never yield more than a modus vivendi. Thus, by obliterating the public-private divide, the open competition model does little to build solidarity in pluralistic post-

${ }^{51}$ Rorty, "Unpatriotic Academy," 252.

52 Id. See also, Rorty, Achieving Our Country, 24, where Rorty dis misses multiculturalism as "a morality of live-and-let-live, a politics of side-by-side development in which members of distinct cultures preserve and protect their own culture against incursions of other cultures."

${ }^{53}$ Rorty, “The Unpatriotic Academy,” 252. 
secular constitutional democracies, and may do a great deal to undermine it. Without solidarity in a shared national identity, there is no shared hope.

Without shared hope, there is no possibility for enduring reform.

Maintaining the public-private divide under the foundation-neutral model, by contrast, presupposes and therefore encourages the development of shared vocabularies. The divide's gate keeping function is to restrict final vocabularies' from public political discourse. In other words, if a political position cannot be articulated in foundation-neutral terms, then it cannot be offered as a public justification for the exercise of political power. Proponents of the model have explained the contents of the foundationneutral vocabulary that should be permitted in public political discourse differently. I have explained it as comprising "free moves" in public political discourse. ${ }^{54}$ John Rawls defined it in terms of "fundamental ideas" that are "implicit in the public politics culture of a democratic society." And Rorty related it in terms of a shared national vocabulary comprising "catchwords" that can be enlisted to "tell inspiring stories about episodes and figures in [a] nation's past—episodes and figures to which the country

\footnotetext{
${ }^{54}$ My own approach, articulated in "Law Beyond God and Kant," is inspired by Robert Brandom's account of the default and challenge structure of the game of giving and asking for reasons. See generally, Robert Brandom, Making it Explicit (Harvard University Press, 1994).

${ }^{55}$ Rawls, Political Liberalism, 13.
} 
should remain true." ${ }^{, 56}$ But what makes all these vocabularies foundationneutral is that they are "freestanding;" they can be enlisted to offer political justifications that are independent of ind ividual citizens' controversial foundational commitments. This has a number of consequences for social solidarity and political authority.

First, the fact that political goals and reforms can only be publicly advocated by appeal to a shared vocabulary under the found ation-neutral model incentivizes the expansion and deepening of this shared national vocabulary. Those who wish to advocate political change (or against it) must do so by availing themselves of tropes that are accessible within political society's shared culture. This may mean drawing on wellestablished national catchwords or shared national memories to justify the status quo. It may also mean working to literalize metaphorical applications of those same catchwords and memories (or introducing new ones) to advocate for reform. ${ }^{57}$ Either way, both the conservative and the liberal will share common ground, and they have incentives to expand and deepen it. By making shared values, traditions, and histories that are implicit in a public political culture explicit in a way that is received by others, participants in political discourse "share that they share" these values,

\footnotetext{
${ }^{56}$ Rorty, Achieving Our Country, 3-4.

${ }^{57}$ See, e.g., Rorty, Contingency, 48.
} 
traditions, and histories. ${ }^{58}$ Through this exercise, a political society celebrates itself, and this is precisely the stuff that solidarity is made of.

Second, the very effort of checking one's final vocabulary at the door when entering the public political sphere signals to others that you respect them that much, and that you are there to cooperate- not dictate. This spirit of cooperation and mutual respect makes it easier for parties who are at odds to soften their positions, making genuine solidarity on a compromise position more likely.

Third, even if consensus is not achieved (it almost never is), and there are clear winners and losers in public political discourse, a strong public-private divide ensures that the loss touches only upon the first-order rules or principles at stake. The loss is not an express rejection of the losers' final vocabulary or private projects of self-creation, as it often would be under the open-competition model. This avoids humiliation, but it also helps to keep the losers at the table and lends legitimacy and authority to even the most controversial of laws or political acts. For, as foundationneutral, even a controversial law or act will have been justified by appeal to a shared vocabulary, and in a spirit of cooperation and mutual respect.

\footnotetext{
${ }^{58}$ See Hubert Dreyfus and Sean Dorrance Kelly, All Things Shining (Free Press, 2011),
} 193. 
IV. HARD CASES AND THE PARADOX OF OPEN COMPETITION

So far I have drawn upon Rorty's work to defend a new, postsecular public-private divide, and to argue that leveling that divide and introducing final vocabularies (religious, racial, ethnic, sexual, gender, philosophical, or other) into the public political sphere to justify laws and the exercise of political power can result in cruelty by forced redescription and undermine solidarity among citizens.

As noted above, the negative effects of the open competition model are often most keenly felt when the courts decide hard cases by appeal to controversial foundational commitments. ${ }^{59}$ I have found that proponents of open competition in public political discourse have a common response to this concern, and it is worth addressing here. Focusing on the distinction between deliberation and decision, they argue that while judges should be free to openly enlist their religious or secular foundational commitments in their deliberations, once the decision is reached, these commitments should then be cleansed from the published decision. For example, though Michael Perry vigorously defends the position that judges should be free to rely on their controversial moral and religious beliefs in deliberation, he recommends that they refrain from expressing these beliefs in their decisions:

\footnotetext{
${ }^{59}$ See supra Section II.
} 
Even when, in the "hard" case, there may be no apparent alternative for a jud ge to give a controversial moral belief as an elementjustification — of her decision, my suggestion is not that she also give the controversial belief (perhaps religious) that in her view supports the controversial moral belief, much less that she undertake a theological or philosophical defense of the supporting belief. ${ }^{60}$

A version of this approach has been advocated by virtually ${ }^{61}$ every proponent of open competition, including Stephen Carter, ${ }^{62}$ Kent Greenawalt, ${ }^{63}$ Sanford Levinson, ${ }^{64}$ and Mark Modak-Truran. ${ }^{65}$

${ }^{60}$ Michael J. Perry, "Religious Morality and Political Choice: Further Thoughts — and Second Thoughts-On Love and Power," San Diego Law Review 30 (1993), 703, 726.

61 I say "virtually" because one proponent of the Open Competition Model, Scott Idleman, appears to be willing to bite the proverbial bullet on this issue and license judges to express religious or other foundational justifications in their published decisions. See, e.g., Scott C. Idleman, "The Concealment of Religious Values in Judicial Decision making," Virginia Law Review 91 (2005), 515, 534.

${ }^{6}$ See, e.g., “The Religiously Devout Judge," Notre Dame law Review 64 (1989) 932, 943.

${ }^{63}$ See, e.g., Greenawalt, Religious Convictions, 239.

${ }^{64}$ See, e.g., Levinson, “Abstinence and Exclusion,” 83.

65 Modak-Truran refers to this approach, that "judges can or should rely on relig ious convictions in their opinions (the process of explanation) but should not rely on religious 
There are two reasons why it is perplexing that proponents of open competition would recommend that jud ges cleanse their published decisions of any reference to the foundational commitments that ultimately justify the result.

First, one of the principal arguments offered in favor of open competition (and against the public-private divide I have advocated) is that there are not sufficient foundation-neutral reasons to support deliberation and justify a decision with respect to difficult constitutional issues. Opening deliberation to foundational commitments, it is argued, will resolve this problem. With this in mind, however, the suggestion that a jud ge separate her deliberation of such important constitutional issues from her published decision makes no sense. If, on the one hand, deliberation and decision cannot be achieved absent appeal to foundational commitments, how is one to make heads or tails of the published decision absent expression of these commitments? If, on the other hand, the jud gment can be fully justified and explained by appeal to foundationneutral reasons in the published decision, then the criticism that a public

convictions in their written opinions (the process of deliberation)," as the "religionistseparationist model." He defends this model in "Reenchanting the Law," 720.; see also Modak-Truran, “The Religious Dimension of Judicial Decision Making and the De Facto Disestablishment," Marquette Law Review 81 (1998), 255. 
political culture's shared vocabulary is insufficiently rich to decide such cases falls flat.

It is no help to defenders of open competition to suggest that the published decision will be justified by appeal to black- letter law and legal precedent alone, for this would not help the judge in filling the gap of legal indeterminacy in hard cases. Alternatively, one could effect the separation of deliberation and decision by leaving justificatory gaps in the published decision where the justification was provided by a controversial foundational commitment, but such justificatory gaps would warrant suspicion of (and speculation at) the judge's motives, thereby placing the legitimacy of the decision in jeopardy. Faced with this risk, the defenders of open competition would be better served by candor.

The second problem for proponents of open competition who recommend that judges deliberate by appeal to final vocabularies but exclude any reference to foundational commitments in their published opinions is that this strategy is self-defeating. If open competition among competing religious and moral foundational commitments is such a good thing, why should it be constrained where it matters most—in the actual published justification for the exercise of the coercive power of the state? Kent Greenawalt suggests the requirement that foundational commitments be excluded from published decisions is explained by the fact that such 
opinions are "supposed to refer only to what is legally relevant."66 And, according to Greenawalt, "[w] hat is legally relevant is generally conceived to be the same for all judges, so neither personal religious convictions nor any other idiosyncratic convictions are legally relevant."67 But this can't be the correct justification because it does not explain the exclusion of foundational commitments from published justification in hard cases where everyone understands that the law is indeterminate and the judge may be required to fill the gap by appeal to extra-legal reasons. One of the principal goals of open competition is to bring out into the open what was once hidden from the public, namely the foundational commitments that were purportedly deciding cases and legislation. Excluding foundational commitments from published decisions because they do not look like "legal" justifications is inconsistent with this goal.

Some proponents of open competition have justified the demand that foundational commitments be excluded from judicial decisions based on the Establishment clause of the First Amendment. ${ }^{68}$ This justification is unsatisfying for a number of reasons. To begin, a number of proponents of open competition dispute the claim that the Establishment clause should be

\footnotetext{
${ }^{66}$ Greenawalt, Religious Convictions, 239.

${ }^{67} I d$.

${ }^{68}$ See, e.g., Modak-Truran, "Reenchanting the Law," 781.
} 
read to exclude religious values from official justification. ${ }^{69}$ But, more importantly, if the Establishment clause were an obstacle to complete implementation of open competition in the United States, proponents of that model should be arguing that this fact gives Americans a reason for amending or reinterpreting this clause.

Ultimately, one is left with the suspicion that there is another reason why proponents of the open competition model suggest that judges exclude final vocabularies from their published justifications. It is because they are good liberals and recognize, with Rorty, that publicly justifying the exercise of coercive power in terms of controversial foundational commitments would cruelly redescribe citizens who do not share those commitments and would undermine the spirit of cooperation and mutual respect that has historically informed the liberal principle of reciprocity. But if this is the true justification for the exclusion, then is this commitment to the liberal reciprocity foundational or freestanding? If it is foundational, then it seems the proponent of open competition will be forced to defend a single comprehensive liberal conception of justice - and she is therefore not really open to competition, but is rather resorting to an Enlightenment universalism to restrict access to public political discourse. If, on the other hand, the justification is freestanding, then, at the end of the day, there

\footnotetext{
${ }^{69}$ See, e.g., Carter, Culture of Disbelief, 106-123.
} 
appears to be little that separates supporters of open competition from those who defend foundation-neutrality in the form of a strong public-private divide - the former reducing to the latter.

\section{CONCLUSION}

In an often-quoted passage, Rorty wrote that 'J.S. Mill's suggestion that governments devote themselves to optimizing the balance between leaving people's lives alone and preventing suffering seems to me pretty much the last word."70 I have tried to show why, for Rorty, maintaining a strong public-private divide that cordons off final vocabularies-the religious, racial, ethnic, sexual, gender, philosophical, and other terms that are so important for citizens' private pursuits of self-creation and selfperfection-from public political discourse is a crucial means to accomplishing both of these goals in post-secular liberal democracies. Public political justifications should instead be articulated in the foundationneutral terms of a shared national vocabulary. Like paintbrushes and crowbars, final and shared vocabularies are different tools for different purposes, and a strong public-private divide helps ensure that no harm comes from their misuse.

The 2016 U.S. presidential campaign placed identity politics at

\footnotetext{
${ }^{70}$ Rorty, Contingency, 63.
} 
center stage, and it was the most divisive in the nation's history. Days after Donald Trump shocked the world by winning the election, a law professor tweeted a passage from Achieving Our Country in which Rorty warned that if America continued on its post-secular tack of leveling liberalism's traditional public-private divide in favor of the politics of difference, "something will crack":

The nonsuburban electorate will decide that the system has failed and start looking around for a strongman to vote for-someone willing to assure them that, once he is elected, the smug bureaucrats . . and postmodernist professors will no longer be calling the shots. ${ }^{71}$ This passage was retweeted thousands of times and generated a run on the book. Amazon sold out in a few days, and The New York Times, in an article titled “Richard Rorty's 1998 Book Suggested Election 2016 Was Coming," reported that Harvard University Press was planning to reprint the book for the first time since $2010 .^{72}$ Though Rorty's concerns went largely unheeded at the close of the twentieth century, people are listening now.

\footnotetext{
${ }^{71}$ Rorty, Achieving Our Country, 90.

72 Jennifer Senior, "Richard Rorty's 1998 Book Suggested Election 2016 Was Coming,” New York Times (Nov. 20, 2016).
} 